\title{
Current practice in laboratory diagnostics of autoimmune diseases in Croatia. Survey of the Working group for laboratory diagnostics of autoimmune diseases of the Croatian Society of Medical Biochemistry and Laboratory \\ Medicine
}

\author{
Andrea Tešija Kuna*1, Lovorka Đerek², Ana Kozmar³, Vedrana Drvar4 \\ ${ }^{1}$ Clinical Institute of Chemistry, Sestre milosrdnice University Hospital, Zagreb, Croatia \\ ${ }^{2}$ Clinical Department for Medical Biochemistry and Laboratory Medicine, Merkur University Hospital, Zagreb, Croatia \\ ${ }^{3}$ University Hospital Centre Zagreb, Department of Laboratory Diagnostics, Zagreb, Croatia \\ ${ }^{4}$ Clinical Department of Laboratory Diagnostics, Clinical Hospital Centre Rijeka, Rijeka, Croatia \\ *Corresponding author: andrea.kuna@gmail.com
}

\begin{abstract}
Introduction: With the trend of increasing incidence of autoimmune diseases, laboratories are faced with exponential growth of the requests for tests relating the diagnosis of these diseases. Unfortunately, the lack of laboratory personnel experienced in this specific discipline of laboratory diagnostic, as well as an unawareness of a method limitation often results in confusion for clinicians. The aim was to gain insight into number and type of Croatian laboratories that perform humoral diagnostics with the final goal to improve and harmonize laboratory diagnostics of autoimmune diseases in Croatia.
\end{abstract}

Materials and methods: In order to get insight into current laboratory practice two questionnaires, consisting of 42 questions in total, were created. Surveys were conducted using SurveyMonkey application and were sent to 88 medical biochemistry laboratories in Croatia for the first survey. Out of 33 laboratories that declared to perform diagnostic from the scope, 19 were selected for the second survey based on the tests they pleaded to perform. The survey comprised questions regarding autoantibody hallmarks of systemic autoimmune diseases while regarding organ-specific autoimmune diseases was limited to diseases of liver, gastrointestinal and nervous system.

Results: Response rate was high with 80 / 88 (91\%) laboratories which answered the first questionnaire, and 19 / 19 (1.0) for the second questionnaire. Obtained results of surveys indicate high heterogeneity in the performance of autoantibody testing among laboratories in Croatia.

Conclusions: Results indicate the need of creating recommendations and algorithms in order to harmonize the approach to laboratory diagnostics of autoimmune diseases in Croatia.

Key words: autoimmune diseases; autoantibodies; survey

\section{Introduction}

Laboratory medicine of autoimmune diseases is a growing discipline of laboratory medicine in general, and many laboratories expand their panel of tests with new methodologies for autoantibody detection. Methods in laboratory medicine of autoimmune diseases differ in many aspects like the antigen profiles, sensitivity and specificity (1). Limitations like the lack of standardized reference samples of defined specificities and different sources of antigens (recombinant vs. native) are the main source of results discrepancy between different methods. Very heterogeneous manner of result reporting is the consequence of both lack of nomenclature uniformity and consensus regarding result interpretation. Finally, the lack of experience and education of laboratory personnel in the diagnostics of certain autoimmune diseases, as well as an unawareness of a method limitation often results 
in confusion for clinicians. Therefore, standardization and harmonization in this field of laboratory diagnostic is essential (2). Efforts were made to provide the recommendations for humoral autoimmune diagnostics that recently resulted with International recommendations for the assessment of anti-nuclear antibody testing published by the European Autoimmunity Standardization Initiative (EASI) (3). For most systemic and organ-specific autoimmune diseases diagnostic criteria or classification criteria have been introduced (4-12). Autoantibodies included in those criteria are an important tool for diagnosis of autoimmune diseases. This prompted the initiative from Croatian Society of Medical Biochemistry and Laboratory Medicine (CSMBLM) to form a Working group (WG) for laboratory diagnostics of autoimmune diseases with following goals: to screen the current practice in performing laboratory medicine of autoimmune diseases in Croatia, to identify the main problems and accordingly propose the recommendations that would improve and harmonize laboratory medicine of autoimmune diseases. The aim of the study was to gather information about the methodology, interpretation and algorithms used in laboratory medicine of autoimmune diseases in Croatia. WG designed two-step questionnaires in order to obtain that information. This study summarises the outcome of these questionnaires and provides the insight into the main problems and sources of heterogeneity in performance of autoantibody testing.

\section{Materials and methods}

In order to obtain information about the current practice in laboratory diagnostics of autoimmune diseases in Croatia two surveys were conducted using SurveyMonkey application (SurveyMonkey Inc., Palo Alto, California, USA). The first survey was a questionnaire that contained 17 questions with predefined answers that aimed to identify laboratories which perform diagnostics of autoimmune diseases and to obtain general information like laboratory organization, number of tests per month, turnaround time (TAT), etc. The contacts of laboratory managers of all medical biochemistry laboratories in Croatia were obtained from Croatian Chamber of Medical Biochemists. The survey was sent to all laboratories within secondary healthcare facilities (general and county hospitals), tertiary healthcare facilities (university hospital/ university hospital centre), private laboratories and specialized health institutions (total number of 88 laboratories). The survey was sent to the email addresses of the laboratory managers with a suggestion that a laboratory professional responsible for laboratory diagnostics of autoimmune diseases should complete the survey. In case that laboratory does not perform any of the tests listed in question two of the first survey, survey participants were instructed to skip all following questions and to conclude the survey. The link for the survey was distributed via e-mails on September $26^{\text {th }} 2014$ and was closed on April 22 ${ }^{\text {nd }} 2015$. The laboratories within primary healthcare facilities were excluded from the survey considering that they do not perform the tests for laboratory diagnostics of autoimmune diseases. After the collection of the responses, from 33 laboratories that declared to perform diagnostic from the scope, 19 were selected for the second survey based on the tests they pleaded to perform. This survey was created in the same application and contained 25 questions in order to obtain more detailed information regarding detection of selected tests. The link for the second survey was also sent via e-mails on October $22^{\text {nd }} 2015$ and was closed on November $28^{\text {th }} 2015$.

For more transparent review, questions and offered answers from both questionnaires are presented together in Table 1.

In total, both questionnaires included 42 questions that could roughly be divided in 6 categories: laboratory organisation, definition of the tests from the scope and organisation of routine work $(\mathrm{N}=8)$, antinuclear antibodies (ANA), antibodies to double stranded DNA (anti-dsDNA) and antibodies to extractible nuclear antigens (anti-ENA) testing ( $N=$ 20), anti-neutrophil cytoplasmic antibodies (ANCA) testing $(\mathrm{N}=6)$, antiphospholipid (aPL) antibodies testing $(\mathrm{N}=3)$, celiac disease $(\mathrm{N}=3)$, autoimmune liver diseases testing $(\mathrm{N}=2)$. 
TABLE 1. Questions, offered and collected answers in CSMBLM WG survey

\begin{tabular}{|c|c|c|}
\hline Question & Answers & $\begin{array}{l}\text { Received answers, } \\
\text { N (\%) }\end{array}$ \\
\hline \multicolumn{3}{|c|}{ First survey $(\mathbf{N}=\mathbf{8 0})$} \\
\hline $\begin{array}{l}\text { 1. Please enter the data of your } \\
\text { institution. }\end{array}$ & Descriptive answer & $80(100)$ \\
\hline \multirow{7}{*}{$\begin{array}{l}\text { 2. Please specify humoral } \\
\text { immunodiagnostic analyses that are } \\
\text { performed in your laboratory? }\end{array}$} & $\begin{array}{l}\text { Systemic autoimmune rheumatic diseases (ANA, ENA, anti-dsDNA, } \\
\text { anti-histones, anti-nucleosomes, CENP, anti-CCP, RF) }\end{array}$ & $30(38)$ \\
\hline & $\begin{array}{l}\text { Systemic vasculitis and glomerulonephritis (ANCA, anti-GBM, } \\
\text { anti-PR3, anti-MPO) }\end{array}$ & $14(18)$ \\
\hline & Autoimmune liver diseases (AMA, AGLM, LKM, LC-1, SLA, ASGPR) & $6(8)$ \\
\hline & Antiphospholipid syndrome (aCL, $\beta 2 \mathrm{GPI}, \mathrm{LA}$, aPS, anti-PT/PS) & $12(15)$ \\
\hline & $\begin{array}{l}\text { Autoimmune bowel diseases (ASCA, APS, EMA, anti-tTG, AGA, } \\
\text { anti-DGP) }\end{array}$ & $11(14)$ \\
\hline & $\begin{array}{l}\text { Autoimmune neurological disorder / paraneoplastic syndrome ( } \\
\text { anti-Hu, anti-Yo, anti-Ri) }\end{array}$ & $2(3)$ \\
\hline & None of the analysis stated above. & $47(59)$ \\
\hline Question & Answers & $\begin{array}{l}\text { Received answers, } \\
\text { N (proportion) }\end{array}$ \\
\hline \multicolumn{3}{|c|}{ First survey for participating laboratories performing humoral immunodiagnostic analyses $(\mathbf{N}=33)^{*}$} \\
\hline \multirow{5}{*}{$\begin{array}{l}\text { 3. What is the type of institution were } \\
\text { your laboratory operates? }\end{array}$} & General/county hospital & $11(0.33)$ \\
\hline & Specialized health institution & $6(0.19)$ \\
\hline & University hospital/University hospital centre & $9(0.27)$ \\
\hline & Private institution & $7(0.21)$ \\
\hline & Other (specify) & $0(0)$ \\
\hline \multirow{4}{*}{$\begin{array}{l}\text { 4. What is the dynamics of providing } \\
\text { laboratory reports? }\end{array}$} & 24 hours & $14(0.42)$ \\
\hline & Up to 7 days & $4(0.13)$ \\
\hline & 7 - 30 days & $14(0.42)$ \\
\hline & $>30$ days & $1(0.03)$ \\
\hline \multirow{3}{*}{$\begin{array}{l}\text { 5. What is the total number of } \\
\text { humoral immunodiagnostic tests per } \\
\text { month in your laboratory? }\end{array}$} & $<500$ & $24(0.73)$ \\
\hline & $500-1000$ & $4(0.12)$ \\
\hline & $>1000$ & $5(0.15)$ \\
\hline $\begin{array}{l}\text { 6. Please state the methods and units } \\
\text { next to the tests (from the list) that } \\
\text { you perform. }\end{array}$ & $\begin{array}{l}\text { Descriptive answer for ANA, ENA, anti-dsDNA, anti-histones, } \\
\text { anti-nucleosomes, CENP, anti-CCP, RF, ANCA, anti-GBM, anti-PR3, } \\
\text { anti-MPO, AMA, SMA, LKM, LC-1, SLA, ASGPR, aCL, anti-B2GPI, LA, } \\
\text { APS, anti-PT/PS, ASCA, APC, EMA, anti-tTG, AGA, anti-DGP, anti-Hu, } \\
\text { anti-Yo, anti-Ri. }\end{array}$ & $\begin{array}{c}33(1.0) \\
\text { (see text and Tables } \\
3-7)\end{array}$ \\
\hline $\begin{array}{l}\text { 7. If you use IIF for ANA determination, } \\
\text { what is your initial dilution? }\end{array}$ & Descriptive answer & $\begin{array}{c}7(0.21) \\
\text { (details in Table 3) }\end{array}$ \\
\hline \multirow{3}{*}{$\begin{array}{l}\text { 8. If you determine ANA with } \\
\text { IIF, do you determine titre of } \\
\text { autoantibodies? }\end{array}$} & Yes & $6(0.18)$ \\
\hline & No & $1(0.03)$ \\
\hline & Depending on the fluorescence type & $0(0)$ \\
\hline \multirow{2}{*}{$\begin{array}{l}\text { 9. If you determine ANA using IIF, do } \\
\text { you describe the type of fluorescence? }\end{array}$} & Yes & $7(0.21)$ \\
\hline & No & $0(0)$ \\
\hline \multirow{4}{*}{$\begin{array}{l}\text { 10. If ANA screening is positive, do } \\
\text { you automatically determine specific } \\
\text { autoantibodies? }\end{array}$} & Yes, depending on the fluorescence pattern & $2(0.06)$ \\
\hline & Yes, depending on the ANA titre & $4(0.12)$ \\
\hline & If requested, independently of ANA-screen test result & $2(0.06)$ \\
\hline & No & $6(0.18)$ \\
\hline
\end{tabular}


11. If you use some other methods instead of IIF for ANA screen, do you specify the antigens included in the test on the laboratory report?

\section{Do you determine the titre of} autoantibodies for analysis (besides ANA) that are tested with IIF? If yes, please state which tests?

\section{If you perform ANCA screening} test by IIF method, do you describe the type of fluorescence? If yes, please state which type of fluorescence you describe.

14. If you determine anti-PR3 and anti-MPO with ANCA-screening, please choose the option that corresponds with your protocol.

\begin{tabular}{lr} 
Yes & $5(0.15)$ \\
\hline No & $5(0.15)$
\end{tabular}

No $6(0.18)$ (details in text)

No

$2(0.06)$

3 (0.09) (details in text)
$0(0)$

They are determined in all samples regardless of the results of ANCA-screening test

\begin{tabular}{lc}
\hline They are determined within ANCA-screening test & $0(0)$ \\
\hline They are only determined in samples that are positive in & $4(0.12)$ \\
ANCA-screening test. &
\end{tabular}

$\begin{array}{ll}\text { Yes } & 5(0.15)\end{array}$

$6(0.18)$

$13(0.39)$

$12(0.36)$

5 (0.15) (details in text)

16. Do you participate in external
quality assessment (EQA) with analysis
stated in Question No. 6. If the answer
is "partially", please specify the
analysis that are included in EQA.

17. Please state the dynamics of participation in EQA schemes.

\begin{tabular}{lc} 
Yes & $13(0.39)$ \\
\hline No & $12(0.36)$ \\
\hline Partially (specify) & $5(0.15)$ (details in text)
\end{tabular}

\begin{tabular}{ll} 
Monthly & $2(0.06)$ \\
\hline Every 2 - 4 months & $5(0.15)$ \\
\hline Every 6 months & $9(0.27)$ \\
\hline Once a year & $2(0.06)$ \\
\hline \multicolumn{1}{c}{ Second survey $(\mathbf{N}=\mathbf{1 9})$} &
\end{tabular}

Second survey $(\mathbf{N}=19)$

\section{Questions}

1. When determining ANA-screen with IIF method, which types of fluorescence do you recognize and report? (Possibility of multiple answers).

2. When determining ANA-screen with IIF do you report different types of fluorescence in the same sample?

\section{Answers}

Received answers, N (proportion)

\begin{tabular}{lc} 
Homogenous & $7(0.37)$ \\
\hline Speckled / granular & $7(0.37)$ \\
\hline Centromeres & $7(0.37)$ \\
\hline Nucleolar & $7(0.37)$ \\
\hline Nuclear envelope & $5(0.26)$ \\
\hline Mitotic apparatus & $4(0.21)$ \\
\hline Fluorescence of cytoplasm & $6(0.32)$ \\
\hline Other (specify) & $4(0.21)$ \\
\hline We do not perform ANA test with IIF & (details in Table 3) \\
\hline We report different types of fluorescence and the corresponding & $2(0.63)$ \\
titres & \\
\hline We report different types of fluorescence but only one titre & $4(0.21)$ \\
\hline We do not report different types of fluorescence & $0(0)$ \\
\hline Other (please describe) & $1(0.05)$ \\
\hline
\end{tabular}




\begin{tabular}{|c|c|c|}
\hline \multirow{4}{*}{$\begin{array}{l}\text { 3. When determining ANA-screen } \\
\text { with IIF, slides are examined by: }\end{array}$} & One examiner & $1(0.05)$ \\
\hline & Two examiners (results are reported in agreement) & $3(0.16)$ \\
\hline & One examiner in consultation with another if needed. & $3(0.16)$ \\
\hline & Other (please describe) & $0(0)$ \\
\hline \multirow{2}{*}{$\begin{array}{l}\text { 4. What is the highest dilution when } \\
\text { you determine ANA titre in IIF ANA } \\
\text { screening? }\end{array}$} & Maximally up to: (please state a dilution) & $\begin{array}{l}5(0.26) \\
\text { (details in Table 3) }\end{array}$ \\
\hline & We dilute till no detectable fluorescence & $2(0.11)$ \\
\hline \multirow{6}{*}{$\begin{array}{l}\text { 5. In which cases after ANA-screen test } \\
\text { do you determine anti-dsDNA? }\end{array}$} & We do not determine anti-dsDNA & $1(0.05)$ \\
\hline & Only when ordered, regardless of the ANA result & $6(0.32)$ \\
\hline & Only when ordered and ANA-screen result is positive & $1(0.05)$ \\
\hline & $\begin{array}{l}\text { Only when ordered and ANA IIF screen result is positive with a } \\
\text { specific type of fluorescence }\end{array}$ & $0(0)$ \\
\hline & $\begin{array}{l}\text { Always with positive ANA result, even if anti-dsDNA was not } \\
\text { ordered. }\end{array}$ & $4(0.21)$ \\
\hline & $\begin{array}{l}\text { Only when ordered and ANA IIF screen result is positive with a } \\
\text { titre higher then (please insert titre) }\end{array}$ & $\begin{array}{c}1(0.05) \\
\text { (details in Table 5) }\end{array}$ \\
\hline \multirow{2}{*}{$\begin{array}{l}\text { 6. Does your laboratory perform } \\
\text { ENA-screening test? }\end{array}$} & Yes & $4(0.21)$ \\
\hline & No & $15(0.79)$ \\
\hline \multirow{10}{*}{$\begin{array}{l}\text { 7. Which autoantibodies are } \\
\text { included in your ENA-screening test? } \\
\text { (Possibility of multiple answers.) }\end{array}$} & anti-SS-A (Ro60) & $4(0.21)$ \\
\hline & anti-Ro52 (TRIM21) & $1(0.05)$ \\
\hline & anti-SS-B & $4(0.21)$ \\
\hline & anti-ribosome $\mathrm{P}$ protein & $1(0.05)$ \\
\hline & anti-U1RNP & $4(0.21)$ \\
\hline & anti-Sm & $4(0.21)$ \\
\hline & anti-Scl-70 (Topoisomerase-1) & $4(0.21)$ \\
\hline & anti-Jo-1 & $4(0.21)$ \\
\hline & anti-CENP & $1(0.05)$ \\
\hline & other (please specify) & $\begin{array}{c}1(0.05) \\
\text { (details in Table 4) }\end{array}$ \\
\hline \multirow{5}{*}{$\begin{array}{l}\text { 8. What method do you use for } \\
\text { ENA-screening test? }\end{array}$} & ELISA & $3(0.16)$ \\
\hline & Immunoblot (Line blot) & $0(0)$ \\
\hline & Multiplex (Luminex) & $0(0)$ \\
\hline & FEIA & $1(0.05)$ \\
\hline & Other (please specify) & $0(0)$ \\
\hline \multirow{2}{*}{$\begin{array}{l}\text { 9. Results of ENA-screening are } \\
\text { expressed as: }\end{array}$} & Semiquantitative (ratio) & $1(0.05)$ \\
\hline & Qualitative (positive/negative) & $3(0.16)$ \\
\hline \multirow{11}{*}{$\begin{array}{l}\text { 10. Which specific ENA antibodies do } \\
\text { you determine? (Possibility of multiple } \\
\text { answers.) }\end{array}$} & We do not determine ENA specific antibodies & $7(0.37)$ \\
\hline & anti-SS-A (Ro60) & $12(0.63)$ \\
\hline & anti-Ro52 (TRIM21) & $5(0.26)$ \\
\hline & anti-SS-B (La) & $12(0.63)$ \\
\hline & anti-ribosome $\mathrm{P}$ protein & $4(0.21)$ \\
\hline & anti-U1RNP & $11(0.58)$ \\
\hline & anti-Sm & $11(0.58)$ \\
\hline & anti-Scl-70 (Topoisomerase-1) & $12(0.63)$ \\
\hline & anti-Jo-1 & $11(0.58)$ \\
\hline & anti-CENP & $10(0.53)$ \\
\hline & other (please specify) & $\begin{array}{c}6(0.32) \\
\text { (details in Table 4) }\end{array}$ \\
\hline
\end{tabular}




\begin{tabular}{|c|c|c|}
\hline \multirow{5}{*}{$\begin{array}{l}\text { 11. Which method do you use for ENA } \\
\text { specific antibodies determination? }\end{array}$} & ELISA & $3(0.16)$ \\
\hline & Immunoblot (Line blot) & $1(0.05)$ \\
\hline & Multiplex (Luminex) & $3(0.16)$ \\
\hline & FEIA & $4(0.21)$ \\
\hline & Other (please specify) & $\begin{array}{c}1(0.05) \\
\text { (details in Table 4) }\end{array}$ \\
\hline \multirow{2}{*}{$\begin{array}{l}\text { 12. Do you use algorithm for anti-ENA } \\
\text { determination? }\end{array}$} & No, we determine everything that has been ordered & $6(0.32)$ \\
\hline & Yes, anti-ENA is analysed depending on the ANA-screening result & $4(0.21)$ \\
\hline \multirow{2}{*}{$\begin{array}{l}\text { 13. Do you have a rule regarding the } \\
\text { frequency of ENA-specificity repeat } \\
\text { testing? If yes, please state the rule. }\end{array}$} & No & $18(0.95)$ \\
\hline & Yes (state the rule) & $\begin{array}{c}1(0.05) \\
\text { (details in text) }\end{array}$ \\
\hline \multirow{2}{*}{$\begin{array}{l}\text { 14. When only anti-dsDNA and/or } \\
\text { anti-ENA have been ordered, you } \\
\text { perform: }\end{array}$} & $\begin{array}{l}\text { ANA-screen test first, and anti-dsDNA/anti-ENA only in the case of } \\
\text { positive ANA }\end{array}$ & $3(0.16)$ \\
\hline & $\begin{array}{l}\text { Anti-dsDNA and/or anti-ENA are determined without } \\
\text { ANA-screening }\end{array}$ & $9(0.47)$ \\
\hline \multirow{4}{*}{$\begin{array}{l}\text { 15. Do you include interpretative } \\
\text { comments on the laboratory report? }\end{array}$} & No & $14(0.74)$ \\
\hline & $\begin{array}{l}\text { Yes, in the case that fluorescence pattern on ANA-screen test } \\
\text { indicates unusual antibodies (e.g. antibodies to Golgi complex, } \\
\text { lysosomes, peroxisomes) }\end{array}$ & $2(0.11)$ \\
\hline & $\begin{array}{l}\text { Yes, in the case that fluorescence pattern on ANA-screen test } \\
\text { indicates other antibodies (e.g. AMA, SMA) }\end{array}$ & $3(0.16)$ \\
\hline & Other (please specify) & $\begin{array}{c}1(0.05) \\
\text { (details in Table 3) }\end{array}$ \\
\hline \multirow{6}{*}{$\begin{array}{l}\text { 16. As a part of celiac disease } \\
\text { screening you determine lgG class } \\
\text { antibodies to: }\end{array}$} & tissue transglutaminase & $2(0.11)$ \\
\hline & deamidated gliadin & $3(0.16)$ \\
\hline & native gliadin & $0(0)$ \\
\hline & endomysium (EMA) & $0(0)$ \\
\hline & $\begin{array}{l}\text { we do not determine lgG class antibodies in celiac disease } \\
\text { screening }\end{array}$ & $6(0.32)$ \\
\hline & we do not perform celiac disease screening & $8(0.42)$ \\
\hline \multirow{5}{*}{$\begin{array}{l}\text { 17. When do you determine IgG class } \\
\text { antibodies in celiac disease screening? }\end{array}$} & Only when there is a complete IgA deficiency & $0(0)$ \\
\hline & When there is a complete lgA deficiency and in children $\leq 2$ years & $3(0.16)$ \\
\hline & In case of decreased IgA or in a complete IgA deficiency & $0(0)$ \\
\hline & $\begin{array}{l}\text { In case of decreased IgA or in a complete IgA deficiency and in } \\
\text { children } \leq 2 \text { years }\end{array}$ & $0(0)$ \\
\hline & Always, together with IgA class antibodies & $2(0.11)$ \\
\hline \multirow{5}{*}{$\begin{array}{l}\text { 18. What is your starting dilution in } \\
\text { ANCA IIF- screening test? }\end{array}$} & $1: 5$ & $0(0)$ \\
\hline & $1: 10$ & $2(0.11)$ \\
\hline & $1: 20$ & $1(0.05)$ \\
\hline & $1: 40$ & $0(0)$ \\
\hline & We do not perform ANCA-screening test & $15(0.79)$ \\
\hline \multirow{7}{*}{$\begin{array}{l}\text { 19. In ANCA IIF-screening test, do you } \\
\text { use formalin-fixed granulocytes? }\end{array}$} & No & $1(0.05)$ \\
\hline & Yes, always with ethanol-fixed granulocytes & $2(0.11)$ \\
\hline & Yes, only in case of ANCA positive test on ethanol-fixed granulocytes & $0(0)$ \\
\hline & $\begin{array}{l}\text { Yes, only in case of pANCA positive test on ethanol-fixed } \\
\text { granulocytes }\end{array}$ & $0(0)$ \\
\hline & $\begin{array}{l}\text { Yes, only in case of atypical pANCA positive test on ethanol-fixed } \\
\text { granulocytes }\end{array}$ & $0(0)$ \\
\hline & Yes, only if ANCA is ordered from gastroenterologist & $0(0)$ \\
\hline & Yes, only in case of positive ANA & $0(0)$ \\
\hline
\end{tabular}




\begin{tabular}{|c|c|c|}
\hline \multirow{2}{*}{$\begin{array}{l}\text { 20. Do you determine other ANCA } \\
\text { specificities except PR3 and MPO } \\
\text { (elastase, lactoferrin, etc.)? If yes, } \\
\text { please specify. }\end{array}$} & Yes (specify) & $0(0)$ \\
\hline & No & $19(1.0)$ \\
\hline \multirow{3}{*}{$\begin{array}{l}\text { 21. In the case of positive liver kidney } \\
\text { microsome (LKM) antibodies with } \\
\text { IIF method, do you automatically } \\
\text { determine LKM-1 specificity? }\end{array}$} & Yes & $3(0.16)$ \\
\hline & No & $0(0)$ \\
\hline & We do not determine anti-LKM with IIF method & $16(0.84)$ \\
\hline \multirow{3}{*}{$\begin{array}{l}\text { 22. In the case of positive AMA with } \\
\text { IIF method, do you automatically } \\
\text { determine AMA-M2 specificity? }\end{array}$} & Yes & $4(0.21)$ \\
\hline & No & $0(0)$ \\
\hline & We do not determine AMA with IIF method & $15(0.79)$ \\
\hline \multirow{7}{*}{$\begin{array}{l}\text { 23. Do you use algorithm when } \\
\text { antiphospholipid antibodies are } \\
\text { ordered? }\end{array}$} & No, only aCL antibodies are determined & $2(0.11)$ \\
\hline & No, only LA is determined & $3(0.16)$ \\
\hline & No, LA and $\mathrm{aCL}$ are determined simultaneously & $0(0)$ \\
\hline & No, aCL and anti-B2GPI are determined simultaneously & $3(0.16)^{* *}$ \\
\hline & No, aCL, anti-B2GPI and LA are determined simultaneously & $3(0.16)$ \\
\hline & $\begin{array}{l}\text { Yes, anti-B2GPI antibodies are determined depending on the } \mathrm{aCL} \\
\text { results }\end{array}$ & $0(0)$ \\
\hline & We do not determine antiphospholipid antibodies & $7(0.37)$ \\
\hline \multirow{3}{*}{$\begin{array}{l}\text { 24. Which isotypes of aCL do you } \\
\text { determine? }\end{array}$} & $\lg G$ and $\lg M$ & $8(0.42)$ \\
\hline & $\lg G, \lg M$ and $\lg A$ & $0(0)$ \\
\hline & We do not determine $\mathrm{aCL}$ & $11(0.58)$ \\
\hline \multirow{3}{*}{$\begin{array}{l}\text { 25. Which isotypes of anti-B2GPI do } \\
\text { you determine? }\end{array}$} & $\lg \mathrm{G}$ and $\lg \mathrm{M}$ & $7(0.37)$ \\
\hline & $\lg G, \lg M$ and $\lg A$ & $0(0)$ \\
\hline & We do not determine anti-B2GPI & $12(0.63)$ \\
\hline
\end{tabular}

Question and answers obtained after personal communication with managers of 7 laboratories that perform IIF method for antibodies detection

1. Who is authorised to perform examination of IIF slides in your laboratory?

\begin{tabular}{lc} 
specialist in medical biochemistry & $4(0.57)$ \\
\hline master of medical biochemistry and laboratory medicine & $2(0.29)$ \\
\hline other (specify) & $1(0.14)$ \\
(details in Table 3)
\end{tabular}

*Out of 80 participating laboratories, 47 declared to not perform humoral immunodiagnostic analyses (see question 2).

**Including laboratory that simultaneously determines aCL, anti-B2GPI and aPS.

ANA $=$ antinuclear antibodies. ENA $=$ extractible nuclear antibodies. anti dsDNA $=$ anti-double stranded DNA. SS-A/Ro60 $=$ AntiSjögren's-syndrome-related antigen A. Ro52 (TRIM21) = Tripartite motif-containing protein 21. SS-B/La = Sjögren syndrome type B antigen. U1-RNP = U1 ribonucleoprotein. $\mathrm{PM} / \mathrm{Scl}=$ Polymyositis/Scleroderma. $\mathrm{PCNA}=$ Pleomorphic cell nuclear antigen. $\mathrm{Sm}=\mathrm{Smith}$ antigen. $\mathrm{SCl}-70=$ topoisomerase I. Jo-1 = histidyl tRNA synthetase. CENP = antibodies targeting centromere proteins. anti-CCP = antibodies targeting synthetic cyclic citrullinated peptides. RF = rheumatoid factor. ANCA = anti-neutrophil cytoplasmic antibodies. anti-PR3 = anti-proteinase 3 antibodies. anti-MPO = anti-myeloperoxidase antibodies. anti-GBM = anti-glomerular basement membrane antibodies. AMA = antimitochondrial antibodies. AGLM = Anti-smooth muscle antibody. LKM = liver-kidney microsomal antibodies. $\mathrm{LC}-1=$ liver cytosol. SLA = soluble liver antigen. $\mathrm{ASGPR}=$ asialoglycoprotein receptor. $\mathrm{aCL}=$ anticardiolipin antibodies. anti-B2GPI = anti-beta2 glycoprotein I antibodies. LA = lupus anticoagulant. aPS = antiphosphatidilserine antibodies. anti-PT/PS= anti-phosphatidylserine/prothrombin antibodies. ASCA = anti-saccharomyces cerevisiae antibodies. APCA = antibodies against parietal cells. EMA = anti-endomysium antibodies. anti-tTG = antibodies against tissue transglutaminase. $A G A=$ antibodies against native gliadin. anti-DGP = antibodies targeting deamidated gliadin peptides. 


\section{Statistical analysis}

Data were collected in the SurveyMonkey application, but due to the small number of laboratories which perform this scope of diagnostics, no statistical analysis could be applied but the data are rather presented as counts and ratios.

\section{Results}

\section{Response on the survey and general information of participated laboratories}

This survey had a remarkably good response with a response rate of $91 \%$ (80 / 88 laboratories) for the first Survey and 1.0 (19 / 19 laboratories) for the second survey. Table 1 summarizes all specific questions and offered answers from both surveys as well as corresponding counts and ratios from received answers with the exception of descriptive answers that are presented in following text or tables.

Out of 80 laboratories, 33 indicated to perform at least one of the autoimmune diagnostic tests offered in the questionnaire. This means that around $40 \%$ of all laboratories within the secondary and tertiary healthcare facilities as well as specialized and private health institutions perform laboratory diagnostic of autoimmune diseases.

General information on aforementioned 33 laboratories including type of laboratory, TAT for tests from the scope, participation in EQA scheme with frequency are available in Table 1 (questions 3, 4 and 17 from the first survey). All nine university hospital/university hospital Centres and half (11 / 20) of general/county hospitals in Croatia perform this laboratory diagnostic. Number of tests per month is available in Table 1 and distribution of the type of laboratory relative to the number of tests per month is presented in Table 2. Regarding the TAT for autoantibody testing, 14 / 33 laboratories declared 24-hour TAT, which mostly refers to rheumatoid factor (RF) and/or antibodies targeting synthetic cyclic citrullinated peptides (antiCCP) (12 / 14 laboratories), while the remaining two are private laboratories performing wider spectrum of tests. This information was obtained with examination of individual responses to question 4 in the first survey (Table 1). According to information available on the web page of Croatian accreditation agency, 6 of 33 laboratories are accredited according to Croatian normative document: Medical laboratories - Requirements for quality and competence (ISO 15189:2012; EN ISO 15189:2012) in the field of humoral laboratory diagnostic of autoimmune diseases.

\section{Current practice in immunodiagnostic of systemic autoimmune rheumatic diseases}

Out of 33 laboratories, 30 have indicated to perform tests from the scope of serologic diagnostic of systemic autoimmune rheumatic diseases (Table 1).

\section{Assessment of RF and anti-CCP}

Tests for serologic diagnostic of rheumatoid arthritis: RF and anti-CCP are performed in 23 of previously mentioned 30 laboratories; 19 perform both tests while 4 laboratories perform only RF and 4 only anti-CCP. Immunoturbidimetry $(N=16)$ is the most frequent method for RF determination, immunonephelometry is used by 4 , and enzymelinked immunosorbent assay (ELISA), fluorescence enzyme immunoassay (FEIA) and latex agglutination in one laboratory each. The most frequent method for anti-CCP determination is electrochemiluminescence immunoassay (ECLIA) which is performed in 10 laboratories, followed by chemiluminescent microparticle immunoassay (CMIA) in 5, FEIA in 4, ELISA in 3 and microparticle enzyme immunoassay (MEIA) in 1 laboratory.

\section{Assessment of ANA, anti-ENA and anti-dsDNA antibodies}

Determination of ANA is performed in 17 of 30 laboratories. Seven of them are laboratories within tertiary healthcare facilities, 5 within secondary health care facilities, 3 specialized institution and 2 are private laboratories. Indirect immunofluorescence assay (IIF) on Hep-2 cells (Human epithelial type 2 cells) as the reference method for ANA detection is used in 7 / 17 laboratories among which 
TABLE 2. Distribution of the number of tests per month in relation to type of laboratory

\begin{tabular}{|c|c|c|c|c|}
\hline \multirow{2}{*}{$\begin{array}{l}\text { Autoimmune } \\
\text { diagnostic tests } \\
\text { per month, } N\end{array}$} & \multirow{2}{*}{$\begin{array}{l}\text { Laboratories performing } \\
\text { autoimmune diagnostic tests, } \\
\qquad \begin{array}{c}\mathrm{N} \text { (proportion); } \\
\mathrm{N}=33\end{array}\end{array}$} & \multicolumn{3}{|l|}{ Laboratory type } \\
\hline & & Category & Total N & N (proportion) \\
\hline \multirow{4}{*}{$<500$} & \multirow{4}{*}{$24(0.73)$} & General/county hospital & \multirow{4}{*}{24} & $9(0.38)$ \\
\hline & & Private laboratory & & $7(0.29)$ \\
\hline & & Specialized institution & & $5(0.21)$ \\
\hline & & University hospital / University hospital centre & & $3(0.12)$ \\
\hline \multirow{2}{*}{$500-1000$} & \multirow{2}{*}{$4(0.12)$} & General/county hospital & \multirow{2}{*}{4} & $2(0.50)$ \\
\hline & & University hospital/ University hospital centre & & $2(0.50)$ \\
\hline \multirow{2}{*}{$>1000$} & \multirow{2}{*}{$5(0.15)$} & University hospital/University hospital centre & \multirow{2}{*}{5} & $4(0.8)$ \\
\hline & & Specialized institution & & $1(0.2)$ \\
\hline
\end{tabular}

6 are within tertiary and 1 within secondary health care facility. Other methods in use and current practice in assessment of ANA are presented in Table 3 .

ENA-screen test is performed in four laboratories while ENA-specific tests are performed in 12 laboratories. Although classic "ENA" term refers only to
SS-A/Ro60, SS-B/La, U1-RNP, Sm, Scl-70 and Jo-1 antigens, it is generally accepted to use the term ENA-specific tests for individual specificities instead of the more proper one, ANA-specific tests. Data regarding current practice in assessment of ENA testing in Croatia is presented in Table 4. About half of laboratories performing ANA testing

TABLE 3. Current practice in assessment of ANA testing

\begin{tabular}{|c|c|}
\hline $\begin{array}{l}\text { Laboratories performing ANA testing } \\
(\mathrm{N}=17)\end{array}$ & $\begin{array}{c}\mathbf{N} \\
\text { (proportion) }\end{array}$ \\
\hline \multicolumn{2}{|l|}{ Method } \\
\hline IIF on Hep-2 cells & $7(0.41)$ \\
\hline FEIA & $6(0.35)$ \\
\hline ELISA & $3(0.18)$ \\
\hline Line - blot & $1(0.06)$ \\
\hline Assessment of ANA by IIF on Hep-2 cells $(N=7)$ & $\begin{array}{c}\mathrm{N} \\
\text { (proportion) }\end{array}$ \\
\hline \multicolumn{2}{|c|}{ 1. Fluorescence patterns on Hep-2 cells recognized and reported: } \\
\hline Homogenous & $7(1.0)$ \\
\hline Speckled & $7(1.0)$ \\
\hline Centromere & $7(1.0)$ \\
\hline Nucleolar & $7(1.0)$ \\
\hline Nuclear envelope & $5(0.71)$ \\
\hline Mitotic apparatus & $4(0.57)$ \\
\hline Fluorescence of cytoplasm & $6(0.86)$ \\
\hline Nuclear dots & $4(0.57)$ \\
\hline PCNA- like pattern & $3(0.43)$ \\
\hline
\end{tabular}




\begin{tabular}{lcc}
\hline & 2. Initial sample dilution: & \\
\hline $1 / 100$ & & $6(0.86)$ \\
$1 / 80$ & 3. Titration: & $1(0.14)$ \\
\hline & & $6(0.86)$ \\
\hline Yes & 4. Titration up to: & $1(0.14)$ \\
No & & $2(0.29)$ \\
\hline & & $2(0.29)$ \\
\hline dilution with the last detectable fluorescence & $1(0.14)$ \\
$1 / 320$ & & $1(0.14)$ \\
$1 / 10,000$ & & $1(0.14)$ \\
we do not determine the titer & & \\
\hline
\end{tabular}

\section{Reporting of different patterns of fluorescence in the same sample:}

Different fluorescence patterns but with only one titre

Different fluorescence patterns with corresponding titres

Different fluorescence patterns without titre

\section{Inclusion of interpretative comment on report:}

Yes, in the case of fluorescence pattern indicating the presence of unusual antibodies (Golgi, lysosomes, peroxisomes, etc)

Yes, in the case of cytoplasmic fluorescence patterns indicating the presence of SMA or AMA.

No interpretative comment on report

\section{Examination of IIF slides:}

Exclusively by one examiner

By two examiners with report issued in agreement

By one examiner in consultation with another if necessary

\section{Examination of IIF slides is done by:}

Specialist in medical biochemistry and laboratory medicine

Master of medical biochemistry and laboratory medicine

Master of molecular biology

Assesment of ANA by methods other than IIF $(\mathrm{N}=10)$

\section{Specification of included antigens on laboratory report}

\begin{tabular}{|c|c|}
\hline Yes & $5(0.5)$ \\
\hline No & $5(0.5)$ \\
\hline Reflex testing for antibody specificities in ANA-sc & $\underset{\text { (proportion) }}{\mathbf{N}}$ \\
\hline No & $6(0.43)$ \\
\hline Yes, depending on the ANA titre & $4(0.29)$ \\
\hline Yes, depending on the fluorescence pattern & $2(0.14)$ \\
\hline If requested, irrespectively of ANA-screen test result & $2(0.14)$ \\
\hline
\end{tabular}


also determines ENA specificities (9 / 17), some perform ANA, ENA-screen test and identification of ENA specificity ( 3 / 17) and one laboratory performs ANA-screen test followed with ENA-screen without identification of specificities. Only one laboratory has the option for the second method for confirmation of ENA-specificity in the case of unclear results (Table 4). Four laboratories perform requested testing for ENA based on the result of ANA-screen test and only one laboratory applies the in- house rule regarding the frequency of repeated testing for ENA-specificities (only in the case of the increase in ANA titre $>2$ times or in the case of change in fluorescence pattern).

Anti-dsDNA testing is performed in 15 laboratories (Table 5). The vast majority of the laboratories performing ANA testing also perform anti-dsDNA testing (15 / 17), either as the only specificity (3 / 17) or together with anti-ENA (12 / 17). None of laboratories declared more than one method for antidsDNA determination, including the laboratory that uses CLIFT (Crithidia luciliae immunofluorescence test).

Only three laboratories declared to perform ANAscreen as the first line test were only anti-dsDNA and/or anti-ENA were requested.

\section{Assessment of antiphospholipid antibodies}

Antiphospholipid (aPL) antibodies are determined in 12 / 33 laboratories. The most frequently determined antibodies are anticardiolipin antibodies (aCL-lgG and aCL-lgM) followed by anti-beta2-glycoprotein I (anti-B2GPI lgG and IgM) antibodies. Lupus anticoagulant (LA) are assessed in $6 / 12$ laboratories, including two specialized for transfusion medicine. Current practise in the assessment of antiphospholipid antibodies is presented in Table 6 . In the case that request refers only to aPL antibodies without antibody specification, none of the laboratories apply any algorithm, but rather determine all available antiphospholipid antibodies (including IgG and IgM isotypes) simultaneously. Out of eight laboratories that determine $\mathrm{aCL}$ antibodies, five report results in GPL-U/mL and MPL-U/mL while three of them report in $\mathrm{U} / \mathrm{mL}$. Units for antiB2GPI antibodies are reported as $\mathrm{U} / \mathrm{mL}$ or $\mathrm{RU} / \mathrm{mL}$.
TABLE 4. Current practice in assessment of ENA testing

\begin{tabular}{|c|c|}
\hline ENA - screen test $(N=4)$ & $\begin{array}{c}\mathbf{N} \\
\text { (proportion) }\end{array}$ \\
\hline \multicolumn{2}{|l|}{ Method } \\
\hline ELISA & $3(0.75)$ \\
\hline FEIA & $1(0.25)$ \\
\hline \multicolumn{2}{|l|}{ Antigens included: } \\
\hline $\begin{array}{l}\text { "Classic" ENA panel: SS-A/Ro60, SS-B/La, } \\
\text { U1-RNP, Sm, Scl-70, Jo-1 }\end{array}$ & $4(1.0)$ \\
\hline $\begin{array}{l}\text { Classic ENA panel + additional specificities: } \\
\text { CENP, Ro52 (TRIM21), RNA-polymerase III, } \\
\text { PM-Scl, PCNA, Fibrillarin, Ribosome-P protein, } \\
\text { Mi-2) }\end{array}$ & $1(0.25)$ \\
\hline \multicolumn{2}{|l|}{ Results reported as: } \\
\hline Qualitative & $3(0.75)$ \\
\hline Semiquantitative (ratio) & $1(0.25)$ \\
\hline ENA - specific tests $(N=12)$ & $\begin{array}{c}\mathbf{N} \\
\text { (proportion) }\end{array}$ \\
\hline \multicolumn{2}{|l|}{ Method } \\
\hline FEIA & $4(0.33)$ \\
\hline ELISA & $3(0.25)$ \\
\hline MIA (Luminex) & $3(0.25)$ \\
\hline LIA & $1(0.08)$ \\
\hline $\mathrm{FEIA}+\mathrm{LIA}$ & $1(0.08)$ \\
\hline \multicolumn{2}{|l|}{ Specificities } \\
\hline SS-A/Ro60 & $12(1.0)$ \\
\hline Ro52 (TRIM21) & $5(0.42)$ \\
\hline SS-B/La & $12(1.0)$ \\
\hline U1-RNP & $11(0.92)$ \\
\hline RNP70 & $3(0.25)$ \\
\hline Sm & $11(0.92)$ \\
\hline Scl-70 & $12(1.0)$ \\
\hline Jo-1 & $11(0.92)$ \\
\hline Ribosome - P protein & $4(0.33)$ \\
\hline CENP & $10(0.83)$ \\
\hline Histones & $3(0.25)$ \\
\hline Nucleosomes & $1(0.08)$ \\
\hline
\end{tabular}

ENA = extractible nuclear antibodies. FEIA = Fluorescence enzyme immunoassay. ELISA = Enzyme-linked immunosorbent assay. MIA = Multiplex bead immunoassay. LIA = Line immunoassay. SS-A/Ro60 = Anti-Sjögren'ssyndrome-related antigen A. Ro52 (TRIM21) = Tripartite motif-containing protein 21. SS-B/La = Sjögren syndrome type $\mathrm{B}$ antigen. $\mathrm{U1}-\mathrm{RNP}=\mathrm{U} 1$ ribonucleoprotein. $\mathrm{PM} / \mathrm{SCl}=$ Polymyositis/Scleroderma. PCNA = Pleomorphic cell nuclear antigen. Sm = Smith antigen. Scl-70 = topoisomerase I. Jo-1 = histidyl tRNA synthetase. CENP = antibodies targeting centromere proteins. $\mathrm{Mi}-2=$ myositis specific antibody. 
TABLE 5. Current practice in assessment of anti-dsDNA testing

\begin{tabular}{|c|c|}
\hline Anti-dsDNA testing $(\mathrm{N}=15)$ & $\stackrel{\mathrm{N}}{\text { (proportion) }}$ \\
\hline \multicolumn{2}{|l|}{ Methods } \\
\hline FEIA & $6(0.4)$ \\
\hline ELISA & $5(0.33)$ \\
\hline MIA (Luminex) & $3(0.2)$ \\
\hline CLIFT & $1(0.07)$ \\
\hline \multicolumn{2}{|l|}{ Results reporting } \\
\hline quantitative & $14(0.93)$ \\
\hline qualitative & $1(0.07)^{*}$ \\
\hline \multicolumn{2}{|l|}{ Units reported } \\
\hline $\mathrm{IU} / \mathrm{mL}$ & $7(0.47)$ \\
\hline $\mathrm{kIU} / \mathrm{L}$ & $2(0.13)$ \\
\hline $\mathrm{U} / \mathrm{mL}$ & $3(0.2)$ \\
\hline $\mathrm{AU} / \mathrm{mL}$ & $2(0.13)$ \\
\hline $\begin{array}{l}\text { Algorithm applied for anti-dsDNA testing } \\
\text { in regards to ANA-screen test } \\
\qquad(N=12)^{* *}\end{array}$ & $\stackrel{\mathrm{N}}{\text { (proportion) }}$ \\
\hline $\begin{array}{l}\text { Only when requested, regardless of the } \\
\text { ANA-screen result }\end{array}$ & $6(0.5)$ \\
\hline As a reflex test on ANA-screen positive result & $4(0.33)$ \\
\hline $\begin{array}{l}\text { Only when requested and ANA-screen result } \\
\text { is positive }\end{array}$ & $1(0.08)$ \\
\hline Only when requested and ANA titer $>1$ / 160 & $1(0.08)$ \\
\hline \multicolumn{2}{|c|}{$\begin{array}{l}\text { *Laboratory that uses CLIFT method. **Answers obtained } \\
\text { for } 12 / 15 \text { laboratories. FEIA = Fluorescence enzyme } \\
\text { immunoassay. ELISA = Enzyme-linked immunosorbent assay. } \\
\text { MIA = Multiplex bead immunoassay. CLIFT = Crithidia luciliae } \\
\text { immunofluorescence test. }\end{array}$} \\
\hline
\end{tabular}

Regarding methods, ELISA is equally used for $\mathrm{aCL}$ and anti-B2GPI (4 laboratories), while FEIA is used in four laboratories for $\mathrm{aCL}$ and in three for antiB2GPI. ELISA method is in use for aPS determination.

\section{Assessment of antibodies associated with systemic vasculitis and glomerulonephritis}

Fourteen laboratories (14 / 33) determine any antibody associated with systemic vasculitis and glomerulonephritis: anti-neutrophil cytoplasmic antibodies (ANCA), anti-proteinase 3 (anti-PR3), antimyeloperoxidase (anti-MPO), anti-glomerular
TABLE 6. Current practice in assessment of antiphospholipid antibodies (aPL)

\begin{tabular}{lc}
\hline \multicolumn{1}{c}{$\begin{array}{c}\text { Antibodies used in determination } \\
\text { of aPL (N= 12) }\end{array}$} & $\begin{array}{c}\mathbf{N} \\
\text { (proportion) }\end{array}$ \\
\hline Only aCL (IgG and IgM) & $2(0.17)$ \\
Only LA & $3(0.25)$ \\
Only anti-B2GPI (IgG and IgM) & $1(0.08)$ \\
aCl (IgG and IgM) + anti-B2GPI (IgG and IgM) & $2(0.17)$ \\
aCl (IgG and IgM) + anti-B2GPI (IgG and IgM) & $3(0.25)$ \\
+ LA & \\
aCl (IgG and IgM) + anti-B2GPI (IgG and IgM) & $1(0.08)$ \\
+ aPS & \\
\hline
\end{tabular}

$\mathrm{aPL}=$ antiphospholipid antibodies. $\mathrm{aCL}=$ anticardiolipin antibodies. anti-B2GPI = anti-beta2 glycoprotein I antibodies. $\mathrm{LA}=$ lupus anticoagulant. $\mathrm{aPS}=$ antiphosphatidilserine antibodies.

basement membrane (anti-GBM) antibodies. All 14 laboratories determine anti-PR3 and anti-MPO ANCA specificities by the following methods: FEIA (7 / 14), ELISA (4 /14), MIA (Luminex) (2 / 14) and immunoblot (IB) (1 / 14). Only four laboratories perform ANCA-screen test. Three of these four laboratories use method of indirect immunofluorescence (IIF) on ethanol-fixed granulocytes while one of them use ELISA test but without specification regarding target antigens. All four laboratories that perform ANCA-screen use the same algorithm: determination of anti-PR3 and anti-MPO specificities only in ANCA-screen positive samples. Formalinfixed granulocytes are used simultaneously with ethanol-fixed granulocytes as substrates in two of three laboratories that perform IIF ANCA-screen while the third laboratory uses only ethanol-fixed granulocytes. ANCA cut off titre is $1 / 10$ in two laboratories and 1 / 20 in one. All three laboratories recognize following ANCA fluorescence patterns: perinuclear (pANCA), cytoplasmic (cANCA), atypical perinuclear (a/pANCA) and one of them also recognizes atypical cytoplasmic (a/cANCA) fluorescence pattern. No ANCA-specificities other than PR3 and MPO are determined. Almost all (13/ 14) laboratories that determine PR3/MPO specificities report results as quantitative: 8 report as $\mathrm{U} /$ $\mathrm{mL}, 2$ as RU/mL, and one of each as $\mathrm{kIU} / \mathrm{L}, \mathrm{IU} / \mathrm{mL}$ 
and $A U / m L$. Only 3 / 14 laboratories declared to perform anti-GBM determination with MIA (Luminex) (Multiplexed bead immunoassay) method in 2 and IIF in 1 of them.

\section{Assessment of antibodies associated with autoimmune liver diseases}

Six laboratories declared to perform determination of antibodies associated with autoimmune liver diseases. Laboratories within tertiary health care facilities (4 / 6) determine all antibodies relevant for autoimmune liver diseases: antimitochondrial antibodies (AMA), smooth muscle antibodies (SMA), anti-liver-kidney microsomal antibodies (anti-LKM), antibodies to liver cytosol (anti-LC-1) and antibodies to soluble liver antigen (anti-SLA). In these laboratories, AMA is determined by IIF method followed with confirmation of AMA-M2 specificity in the case of positive result. AMA titre is reported in 2 / 4 laboratories while in other two results are reported only as positive or negative. Titre of SMA antibodies is reported in 2 / 4 laboratories, one reports qualitative result and one did not specify the way of reporting the results. AntiLKM antibodies are determined by IIF method followed with confirmation of LKM-1 in the case of positive result in 3 / 4 laboratories. Only one laboratory declared to report the titre of anti-LKM antibodies. The other two of six laboratories that declared to determine antibodies associated with autoimmune liver diseases, determine only anti-LKM and AMA in one of them and anti-LKM only in other. In both cases, solid assays are used (FEIA for AMA and ELISA for anti-LKM). None of the laboratories determines antibodies targeting asialoglycoprotein receptor (ASGPR).

\section{Assessment of antibodies associated with autoimmune diseases affecting the gastrointestinal system}

In total, 11 of 33 laboratories declared to determine any of antibodies associated with gastrointestinal autoimmune diseases. All of them determine antibodies associated with celiac disease (Table 7) Regarding antibodies associated with inflammatory bowel diseases (ulcerative colitis and
TABLE 7. Current practice in immunodiagnostic of celiac disease

\begin{tabular}{lc}
\hline $\begin{array}{c}\text { Antibodies used in immunodiagnostic of } \\
\text { celiac disease }(\mathbf{N}=\mathbf{1 1})\end{array}$ & $\begin{array}{c}\mathbf{N} \\
\text { (proportion) }\end{array}$ \\
\hline \multicolumn{2}{c}{ Methods used for anti-tTG determination $(\mathbf{N}=\mathbf{1 1})$} \\
ELISA & $3(0.27)$ \\
FEIA & $5(0.45)$ \\
MIA (Luminex) & $2(0.18)$ \\
Immunocromatography & $1(0.09)$ \\
\hline
\end{tabular}

Methods used for anti-DPG determination $(\mathbf{N}=\mathbf{5})$

FEIA $3(0.6)$

MIA (Luminex)

$2(0.4)$

Methods used for EMA determination $(\mathrm{N}=4)$

IIF

$3(0.75)$

ELISA

$1(0.25)$

Methods used for AGA determination $(\mathrm{N}=3)$

MIA (Luminex)

$2(0.67)$

FEIA

$1(0.33)$

IgG class of antibodies associated with celiac disease $(\mathbf{N}=\mathbf{5})$

Anti-tTG-lgG

$2(0.4)$

Anti-DGP-lgG

$3(0.6)$

Algorithms in diagnosis of celiac disease $(\mathbf{N}=11)$

Measurement of total $\lg A$ precedes determination of IgA class antibodies

$5(0.45)$

IgG class of antibodies associated with celiac disease determined only in the cases of $\lg \mathrm{A}$ deficiency and in children $\leq 2$ years old.

IgG class of antibodies associated with celiac disease always determined together with $\lg \mathrm{A}$ class antibodies.

anti-tTG = antibodies against tissue transglutaminase. ELISA = Enzyme-linked immunosorbent assay. FEIA = Fluorescence enzyme immunoassay. MIA = Multiplex bead immunoassay. anti-DGP = antibodies targeting deamidated gliadin peptides. EMA = anti-endomysium antibodies. IIF = Indirect immunofluorescence. AGA = antibodies against native gliadin.

Crohn's disease), determination of ANCA antibodies is already stated within the results regarding antibodies associated with systemic vasculitis while anti-saccharomyces cerevisiae (ASCA) antibodies are determined in only one, private laboratory using ELISA method. No laboratories declared to determine any other antibody associated with inflammatory bowel diseases. Antibodies against 
parietal cells (APCA) are determined in only two laboratories, both within tertiary health care facilities and both use IIF method.

\section{Assessment of antibodies associated with autoimmune diseases affecting nervous system}

These antibodies are most rarely determined, in only two laboratories within tertiary healthcare facilities. In both laboratories, antibodies associated with paraneoplastic neurological syndrome are determined: anti-Hu, anti-Yo and anti-Ri antibodies. One laboratory uses only IIF method while the other one uses IIF followed with immunoblot (IB) method for confirmation.

\section{External quality assessment}

Out of 33 laboratories that perform autoimmune diagnostic tests, only 13 participate in external quality assessment (EQA) with the full scope of the analysis (Table 1). Three laboratories have not provided answer to EQA question in the Survey.

One of five laboratories that partially participated in EQA did not specify the tests that are included, while the participation of other four was heterogeneous regarding the tests. Six out of twelve laboratories that do not participate in EQA are laboratories that perform only RF and/or anti-CCP, or LA exclusively in 2 / 12. Also, 2 / 12 laboratories that do not participate with any of the analysis they perform stated the intention to fully participate in EQA starting with the beginning of the following year.

\section{Discussion}

Results of conducted survey confirmed not only high heterogeneity in the performance of autoantibody testing among laboratories in Croatia, but also obsolete in some cases. This includes issues with result reporting, determination of serological markers that are not recommended, methods of determination of certain markers that do not comply with existing international recommendations or the application of very heterogeneous algorithms among laboratories.
Most of the laboratories perform tests for immunodiagnostic of systemic autoimmune rheumatic diseases (SARD), predominantly serological markers of rheumatoid arthritis, RF and anti-CCP. This result was expected taking into account a few facts: a) RA is the most common systemic autoimmune disease, b) both markers are part of RA classification criteria (5), c) both markers are determined using methods set to automatic analysers, which already exist in most laboratories and do not require additional equipment. These automated methods for determining RF and anti-CCP are responsible for the fact that many laboratories (12 of 14) report the analysis results in this field of laboratory diagnostics within 24 hours. After RF and anti-CCP, ANA is the most commonly performed test (17 / 80 laboratories in total). In comparison with the study conducted by the EASI group (13) regarding the implementation of the ANA test in 12 European countries, the number of laboratories performing ANA regarding the total population in Croatia is comparable with France, the Netherlands and Switzerland. Half of the laboratories in Croatia that determine ANA belong to University hospital or University hospital centres while in most European countries to general hospitals or private institutions (with the exception of Norway and Sweden, where the ratio is equal). In order to meet the increasing demand for ANA determination, reducing costs and compensating the lack of experienced personnel for interpretation of ANA fluorescence, the preference to the alternative solid phase automated assays with very diverse sensitivity and specificity is often given over IIF screening method. The main reason for this diversity lies in the fact that commercial kits from different manufactures use different methods, mixture of purified extracts or recombinant antigens, and number of antigens included in mixture $(14,15)$. Using IIF method on Hep-2, larger number of nuclear, nucleolar and cytoplasmic antigens could be detected when compared to solid phase assays where detection is possible only for antigens included in the mixture. Sensitivity and specificity of ANA-screen using enzyme-based immunoassay (EIA) were examined for nine manufactures kits in study of Tan et al. (16). Results showed good sensitivity and specificity with the need for improve- 
ment in detection of anti-dsDNA and anti-Sm in some kits. Sensitivity and specificity using different methods and comparing them to IIF, show different results depending on used method (14-17). Due to significant number of false negative results when using these methods, IIF method on Hep-2 cells is still considered a reference method for ANA screening $(3,14)$. However, one should keep in mind that choice of ANA detection method is actually disease-dependent. For example, ANA is the serologic marker of autoimmune hepatitis but without clearly associated antigen specificity and therefore IIF method is the only one applicable in this case (10). On the other hand, myositis is associated with Jo-1 antibodies which can be accurately detected only with solid phase assays $(2,14)$. Since laboratory staff is mostly unaware of suspected diagnosis, some authors support the opinion that multiple screening tests should be used in order to improve the diagnostic of autoimmune diseases but with appropriate comments included for interpretation of discrepant results $(18,19)$. With the share of only 7 / 17 laboratories that perform ANAscreening with IIF method, Croatia is next-to-last in comparison to European countries that participated in EASI group Survey (13). In fact, in most European countries IIF method is applied in $>90 \%$ of laboratories with the exception of the Netherlands, Portugal, Norway and Ukraine (with 65\%, $64 \%, 50 \%$ and $40 \%$ share respectively). The manner of conducting ANA-screen with IIF in Croatia is rather homogenous, in the sense that all laboratories recognize and report at least 4 regular fluorescence patterns and all except one provide titre and interpretative comments. Given that low ANA titres are common in the older population as well as in some other diseases in addition to SARD, qualitative ANA result does not give sufficient clinical information (14). Beside four regular nuclear patterns, cytoplasmic fluorescence patterns are very common and usually address the presence of other antibodies such as antimitochondrial (AMA) or smooth muscle antibodies (SMA) associated with autoimmune liver diseases (3). Also, cytoplasmic fluorescence can reflect the presence of other important SARD-associated antibodies such as those targeting ribosomal-P proteins or Ro52 (14). Therefore, negligence of cytoplasmic fluorescence can have clinical consequences such as delay in proper diagnosis. Although initial (screening) dilutions most commonly present throughout literature are $1 / 80$ or $1 / 160$, it is generally recommended that the laboratory appoints the initial dilution that corresponds to 95th percentile of local healthy population (with respective shares regarding age and gender) $(1,3)$. However, very often the IIF reagent kit manufacturer proposed initial dilution is applied. Given the fact that Croatia is a small market, the same reagent manufacturer probably recommends the initial dilution $1 / 100$ used by $6 /$ 7 laboratories. Distinct heterogeneity still exists in the titration level of positive samples with only two laboratories following the recommendation of reporting the last dilution which still shows reactivity (3). In addition, heterogeneity exists in reporting different patterns with different fluorescence intensity observed in one sample. Positive finding is that all except one laboratory performing ANA-screen by IIF method consider the opportunity of more than one observer in the case of a doubtful result. Surprisingly poor result of the survey was that half $(5 / 10)$ of laboratories that use solid phase assays for ANA-screening do not specify antigens included in the assay (3). If the clinician is not aware that applied method covers only the limited number of antigens, one can consider it equivalent to IIF screening assay. Commercial solid phase assays usually include clinically most relevant antigens such as SS-A/Ro60, SS-B/La, Sm, U1RNP, dsDNA, Scl-70, Jo-1 and CENP. However, some antigens clinically relevant for systemic sclerosis, such as RNA-polymerase III or some nucleolar antigens such as PM-SCL or fibrillarin are rarely included in these assays $(3,8)$. The same refers to histones as the target antigens for ANA associated with drug induced lupus, which are rarely included in ANA-screen solid phase assays so that the false negative ANA result can lead to misdiagnose (3).

Most laboratories that perform ANA testing also perform anti-ENA testing. However, the approach to ANA and anti-ENA testing is quite heterogeneous and even pointless in some cases (ANA solid assay followed with ENA-screen assay). According to current practice, anti-ENA determination in Croatia is somewhat lower (77\%) in comparison to other European countries (except Ukraine) where 
more than $83 \%$ of laboratories that perform ANA testing also perform anti-ENA testing $(13,20)$. At least, the most relevant ENA antigens (SS-A/Ro60, SS-B/La, Sm, U1RNP, Scl-70, and Jo-1) are included in all ENA-screen assays. Regarding the identification of ENA specificities, all laboratories determine antibodies to SS-A/Ro60, SS-B/La, RNP and Scl-70 while one laboratory does not test for Sm and Jo-1 antibodies. In general, the extent of ENA-specificities determination is lower in Croatia in comparison to other European countries but the covered specificities are comparable (13). Distinction between anti-SS-A/Ro60 and anti-Ro52 (TRIM21) antibodies was found in 42\% (5 / 12) of Croatian laboratories which determines ENA specificities, in comparison to only $20-25 \%$ of laboratories in other European countries. On the one hand it could be attributed to the higher awareness of different clinical relevance regarding monoreactivity to Ro52 antigen (in myositis and systemic sclerosis) or SS-A/ Ro60 antigen (in subacute lupus) (21). On the other hand, some laboratories do not use single tests for specificity confirmation but in order to reduce the cost and time for analysis, rather use the panel of different specificities. Therefore, it could be that number of individual specificities is simply dictated by the available commercial products. Another interesting finding is that $3 / 12$ laboratories determine RNP70 specificity either with or without U1RNP specificity (encompasses proteins A, C, and 70kD). Although the anti-U1RNP immune response targets all three protein components $(70 \mathrm{kDa}, \mathrm{A}, \mathrm{C})$, individual reactivity to $70 \mathrm{kDa}$ protein may be more specific for mixed connective tissue disease (MCTD) as it is less frequent in SLE than those to proteins $A$ or C (22). However, the best sensitivity and specificity for MCTD seems to be achieved with identification of both U1RNP and RNP70 (23).

In spite of recommendation to use additional method in the case of result discrepancy between anti-ENA and ANA or with clinical suspicion, only one laboratory has the opportunity of using alternative method for anti-ENA (3).

Regarding anti-dsDNA testing, none of laboratories use Farr assay (radioimmunoassay, RIA) that is based on precipitation of antibody-antigen complexes using ammonium sulphate and the quanti- fication of antibody in the precipitate using a radio-labelled dsDNA antigen. Farr assay is considered to be the gold standard but it is also minimally present in laboratories throughout Europe, most probably due to use of radioisotopes and laboriousness of the method (24). CLIFT as a second choice according to specificity is variable present (26-94\%) in European laboratories while in Croatia only one laboratory uses this method (13). However, no quantitative method for detection of antidsDNA is in use in this laboratory so that the patient cannot be followed. Although all except one laboratory report quantitative result for anti-dsDNA there is considerable heterogeneity in reporting units. Since commercial tests are calibrated against the 1st International Standard for anti-dsDNA coded Wo/80, results should be given in International Units (IU/mL).

The majority of laboratories do not apply algorithms for testing anti-ENA or anti-dsDNA based on ANA-screen result but strictly adhere to the requested tests. The most probable explanation is that the Croatian health reimbursement policy does not consider reflex testing.

Most laboratories do not apply any rules regarding minimal retesting interval. This issue primarily refers to frequent requests for ANA retesting or for retesting of previously confirmed ENA-specificity. Repeat testing for ANA titre does not have confirmed value in assessing the disease activity and retesting for ENA-specificity can be justified only in the case of the appearance of new symptoms (2). Our data are comparable to the results of Canadian study that pointed out unnecessary repeat testing and simultaneous ordering of multiple tests (ANA, ENA, dsDNA) (25).

General impression of the Survey results regarding ANA testing is that the consultative role of laboratory experts in immunodiagnostic workout is poorly involved or limited only to an interpretative comment, eventually.

Testing for antiphospholipid antibodies is performed in 15\% (12 / 80) of laboratories within tertiary and secondary health care facilities and private health care institutions. The minority of laboratories covers determination of all antibodies in- 
cluded in APS-classification criteria (9). It can partially be explained with the policy in some hospitals to perform determination of LA within the framework of transfusion medicine instead of medical biochemistry laboratory. There is considerable heterogeneity regarding reporting of the units for anticardiolipin antibodies with almost half of laboratories not following the International guidelines on anticardiolipin testing (26).

Assessment of antibodies associated with systemic vasculitis and glomerulonephritis is performed in $17 \%$ (14 / 80) of included laboratories. The current approach of ANCA determination in Croatian laboratories implies quantitative (in all but one laboratory) determination of PR3 and MPO specificities only, while ANCA-screen is performed in minority of laboratories. All three laboratories that use IIF method for ANCA-screen apply the same algorithm with obligatory testing for PR3/MPO specificity in ANCA IIF positive samples and also recognize and report the fluorescence patterns in line with International consensus statement on testing and reporting of ANCA $(27,28)$. Use of qualitative test for PR3/MPO specificities is limited to diagnosis purpose in emergency cases and, unlike quantitative test, has no value in monitoring the inflammatory activity of vasculitis.

Assessment of autoantibodies associated with autoimmune liver diseases is poorly present in Croatian laboratories and is mostly limited to laboratories within University hospitals. There is considerable heterogeneity in the approach to determination of SMA and LKM antibodies by IIF method concerning reporting titre. Namely, half of laboratories do not report titre for SMA while for antiLKM all except one do not report titre. This policy is not in line with the guidelines of International Autoimmune Hepatitis Group which includes a Scoring System for diagnosis of autoimmune hepatitis based on the titre of relevant autoantibodies (ANA, SMA, LKM) (29-31). For the same reason, use of solely solid assays for detection of anti-LKM antibodies is not suitable, but should rather be used for confirmation of LKM-1 reactivity in samples with LKM-typical fluorescence pattern. Although, determination of AMA titre has no approved clinical value, half of laboratories report titre.
Among antibodies associated with gastrointestinal autoimmune diseases, determination of those associated with celiac disease are most frequently performed, with anti-tTG $\lg \mathrm{A}$, as the first line test, being the most prominent. Antibodies to native gliadin (AGA) are still sporadically determined although all the relevant guidelines discourage use of these antibodies in diagnosis of celiac disease $(12,32)$. Algorithms applied in serologic diagnosis of celiac disease are heterogeneous and almost half laboratories do not follow the guidelines on the determination of IgG class of antibodies or total $\lg A$ (12).

Regarding antibodies associated with inflammatory bowel diseases (IBD) it is important to point out that ANCA associated with these diseases targets a wide range of possible antigens but not PR3 and MPO (33). IBD associated ANCA are commonly detected only by IIF method without confirmation of specificity. Using the term "ANCA" for specific antiPR3 or anti-MPO tests can be misleading for clinician seeking for ANCA in IBD. ANCA specificities relevant for IBD are not detected in the Croatian public medical laboratories and also rarely in private laboratories.

Determination of antibodies associated with autoimmune diseases affecting nervous system is most rarely performed and are limited only to antibodies in paraneoplastic syndrome.

Considering participation in EQA, the results clearly show that not enough laboratories participate in EQA schemes. This could partially be explained by the fact that the national program for external control provided by the Croatian Centre for Quality Assessment in Laboratory Medicine (CROQALM) does not cover tests from this scope. Participation in EQA is especially important for autoantibody testing since these methods are not standardized and use exclusively manufacturer - dependent quality control samples which makes the objective evidence of laboratory competence limited (34). Participation in EQA offers the opportunity for laboratory to compare own results with those obtained with other participants that use same or different methodologies (35). The efforts to motivate or obligate laboratories to participate in EQA 
schemes should be made with a help of national professional associations. This process could also be facilitated with the decision to participate in the accreditation process according to HRN EN ISO 15189 in the field of humoral laboratory diagnostic of autoimmune diseases.

Considering all challenges that our study indicates, the Italian multicentre study showed how development and implementation of diagnostics algorithms and recommendations contribute to diagnostic specificity of autoimmune rheumatic diseases (36). Limitation of this study could be attributed to all the disadvantages of using online survey to collect data about current practice in laboratory diagnostics of autoimmune diseases in Croatia. The main disadvantage is that the answers to the questions depend on respondents' honesty regarding the real situation in laboratory practice of autoimmune diseases diagnostics. The other limitation of the study is limited number of organspecific autoimmune diseases included.

\section{References}

1. Melegari A, Bonaguri C. Harmonization of autoimmune diagnostics with antinuclear antibody testing algorithm: Approach of appropriateness and clinical relevance. Isr Med Assoc J 2014;16:640-2.

2. Kavanaugh A, Tomar R, Reveille J, Solomon DH, Homburger $H A$. Guidelines for clinical use of the antinuclear antibody test and tests for specific autoantibodies to nuclear antigens. Arch Pathol Lab Med 2000;124:71-81.

3. Agmon-Levin N, Damoiseaux J, Kallenberg C, Sack U, Witte $T$, Herold $M$, et al. International recommendations for the assessment of autoantibodies to cellular antigens referred to as anti-nuclear antibodies. Ann Rheum Dis 2014;73:1723. http://dx.doi.org/10.1136/annrheumdis-2013-203863.

4. Hochberg MC. Updating the American College of Rheumatology revised criteria for the classification of systemic lupus erythematosus. Arthritis Rheum 1997;40:1725. http:// dx.doi.org/10.1002/art.1780400928.

5. Aletaha $D$, Neogi $T$, Silman AJ, Funovits J, Felson DT, Bingham CO, et al. 2010 Rheumatoid arthritis classification criteria: an American College of Rheumatology/European League Against Rheumatism collaborative initiative. Arthritis Rheum 2010;62:2569-81. http://dx.doi.org/10.1002/ art.27584.

6. Vitali C, Bombardieri S, Jonsson R, Moutsopoulos HM, Alexander EL, Carsons SE et al. European Study Group on Classification Criteria for Sjogren's Syndrome. Classification criteria for Sjogren's syndrome: a revised version of the Eu-
In conclusion, the survey results indicate the heterogeneity in the manner of conducting the humoral immunodiagnostic of autoimmune diseases throughout laboratories in Croatia. This heterogeneity refers not only to the use of different methods, analytical platforms or algorithms but also to the use of the same method and to the policy of results reporting. Such heterogeneity on the level of laboratory diagnostics most certainly has an impact on the clinical level. Therefore, presented data stressed out the necessity for recommendations on national level with the aim to harmonize this specific branch of laboratory diagnostic. In issuing recommendations, currently used methodologies as well as the national health reimbursement policy, which for example, does not consider reflex testing should be taken into the consideration.

\section{Potential conflict of interest}

None declared.

ropean criteria proposed by the American-European Consensus Group. Ann Rheum Dis 2002;61:554-8. http://dx.doi. org/10.1136/ard.61.6.554.

7. Sharp GC, Irvin WS, Tan EM, Gould RG, Holman HR. Mixed connective tissue disease - an apparently distinct rheumatic disease syndrome associated with a specific antibody to an extractable nuclear antigen (ENA). Am J Med 1972;52:14859. http://dx.doi.org/10.1016/0002-9343(72)90064-2.

8. van den Hoogen F, Khanna D, Fransen J, Johnson SR, Baron M, Tyndall A, et al. 2013 classification criteria for systemic sclerosis: an American College of Rheumatology/European League against Rheumatism collaborative initiative. Arthritis Rheum 2013;65:2737-47. http://dx.doi.org/10.1002/ art.38098.

9. Miyakis S, Lockshin MD, Atsumi T, Branch DW, Brey RL, Cervera $R$, et al. International consensus statement on an update of the classification criteria for definite antiphospholipid syndrome (APS). J Thromb Haemost 2006;4:295-306. http:// dx.doi.org/10.1111/j.1538-7836.2006.01753.x.

10. Alvarez F, Berg PA, Bianchi FB, Bianchi L, Burroughs AK, Cancado EL, et al. International Autoimmune Hepatitis Group Report: review of criteria for diagnosis of autoimmune hepatitis. J Hepatol 1999;31:929-38. http://dx.doi. org/10.1016/S0168-8278(99)80297-9.

11. Bataller L, Dalmau JO. Paraneoplastic disorders of the central nervous system: update on diagnostic criteria and treatment. Semin Neurol 2004;24:461-71. http://dx.doi. org/10.1055/s-2004-861540. 
12. Husby S, Koletzko S, Korponay-Szabo IR, Mearin ML, Phillips $J A$, Shamir R, et al. European Society for Pediatric Gastroenterology, Hepatology, and Nutrition Guidelines for the diagnosis of coeliac disease. JPGN 2012;54:136-60. http:// dx.doi.org/10.1097/mpg.0b013e31821a23d0.

13. Damoiseaux J, Agmon-Levin N, Van Blerk M, Chopyak V, Eriksson C, Heijnen I et al. From ANA-screening to antigenspecifity: an EASI-Survey on the daily practice in European countries. Clin Exp Rheumatol 2014;32:0539-46.

14. Mahler M, Meroni PL, Bossuyt X, Fritzler MJ. Current concepts and future directions for the assessment of autoantibodies to cellular antigens referred to as anti-nuclear antibodies. Journal of Immunology Research 2014, Article ID 315179. http://dx.doi.org/10.1155/2014/315179.

15. Baronaite R, Engelhart M, Mørk Hansen T, Thamsborg $G$, Slott Jensen $H$, Stender $S$ et al. A comparison of anti-nuclear antibody quantification using automated enzyme immunoassays and immunofluorescence assays. Autoimmune Diseases 2014, Article ID 534759. http://dx.doi. org/10.1155/2014/534759.

16. Tan EM, Smolen JS, MCDougal JS, Butcher BT, Conn D, Dawkins $R$ et al. A critical evaluation of enzyme immunoassays for detection of antinuclear autoantibodies of defined specificities. Arthrits \& Rheumatism 1999;42:455-64. http:// dx.doi.org/10.1002/1529-0131(199904)42:3<455::AIDANR10>3.0.CO;2-3.

17. Copple SS, Sawitzke DA, Wilson MA, Tebo EA, Harry R, Hill $R H$. Enzyme-linked immunosorbent assay screening then indirect immunofluorescence confirmation of antinuclear antibodies. Am J Clin Pathol 2011;135:678-84. http://dx.doi. org/10.1309/AJCP6R8EELGODAYW.

18. Bossuyt $X$, Fieuws S. Detection of antinuclear antibodies: added-value of solid phase assays? Ann Rheum Dis 2014;73:e10. http://dx.doi.org/10.1136/annrheumdis-2013-204793.

19. Agmon-Levin N, Damoiseaux J, Shoenfeld Y. Letter response: Response to "Detection of antinuclear antibodies: added-value of solid phase assays?" by Bossuyt and Fieuws. Ann Rheum Dis 2014;73:e11. http://dx.doi.org/10.1136/ annrheumdis-2013-204797.

20. Van Blerk $M$, Bossuyt $X$, Humbel $R$, Mewis $A$, Servais $G$, Tomasi JP et al. Belgian recommendations on ANA, anti-dsDNA and anti-ENA antibody testing. Acta Clin Belg 2014;69:83-6. http://dx.doi.org/10.1136/annrheumdis-2013-204797.

21. Menéndez A, Gómez J, Escanlar E, Caminal-Montero L, Mozo L. Clinical associations of anti-SSA/Ro60 and antiRo52/TRIM21 antibodies: Diagnostic utility of their separate detection. Autoimmunity 2013;46:32-9. http://dx.doi.org /10.3109/08916934.2012.732131.

22. Hof D, Cheung K, de Rooij DJRAM, van den Hoogen FH, Pruijn GJM, van Venrooij WJ, et al. Autoantibodies specific for apoptotic U1-70K are superior serological markers for mixed connective tissue disease. Arthritis Res Ther 2005;7:R302-9. http://dx.doi.org/10.1186/ar1490.

23. Luyckx A, Westhovens $R$, Oris E, Papisch W,Bossuyt X. Clinical Relevance of Measurement of Antibodies to Individual snU1-RNP Proteins. Clin Chem 2005;51:1888-90. http:// dx.doi.org/10.1373/clinchem.2005.053652.

24. Sherer Y, Gorstein A, Fritzler MJ, Shoenfeld Y. Autoantibody explosion in systemic lupus erythematosus: more than 100 different antibodies found in SLE patients. Semin Arthritis Rheum 2004;34:501-37. http://dx.doi.org/10.1016/j.semarthrit.2004.07.002.

25. Man A, Shojania K, Phoon C, Pal J, Hudoba de Badyn M, Pi $D$ et al. An evaluation of autoimmune antibody testing patterns in a Canadian health region and an evaluation of a laboratory algorithm aimed at reducing unnecessary testing. Clin Rheumatol 2013; 32:601-8. http://dx.doi. org/10.1007/s 10067-012-2141-y.

26. Lakos G, Favaloro EJ, Harris EN, Meroni PL, Tincani A, Wong $R C$ et al. International consensus guidelines on anticardiolipin and anti-2-glycoprotein I testing. Report from the 13th International Congress on Antiphospholipid Antibodies. Arth Rheum 2012;64:1-10. http://dx.doi.org/10.1002/ art.33349.

27. Savige J, Gillis D, Benson E, Davies D, Esnault V, Falk RJ et al. International Consensus statement on testing and reporting of antineutrophil cytoplasmic antibodies (ANCA). Am J Clin Pathol 1999;111:507-13. http://dx.doi.org/10.1093/ ajcp/111.4.507.

28. Savige J, Dimech W, Fritzler M, Goeken J, Hagen EC, Jennette $C$ et al. Addendum to the International Consensus Statement on testing and reporting of antineutrophil cytoplasmic antibodies. Quality control guidelines, comments, and recommendations for testing in other autoimmune diseases. Am J Clin Pathol 2003;120:312-18. http://dx.doi. org/10.1309/WAEPADWOK4LPUHFN.

29. Manns MP, Czaja AJ, Gorham JD, Krawitt EL, Mieli-Vergani G, Vergani D, et al. Diagnosis and Management of Autoimmune Hepatitis. Hepatology 2010;51:2193-213. http:// dx.doi.org/10.1002/hep.23584.

30. Manns MP, Lohse AW, Vergani D. Autoimmune hepatitis update 2015. J Hepatol 2015;62:S100-111. http://dx.doi. org/10.1016/j.jhep.2015.03.005.

31. Yeoman AD, Westbrook RH, Al-Chalabi T, Carey I, Heaton ND, Portmann $B C$, et al. Diagnostic value and utility of the simplified international autoimmune hepatitis group (IAIHG) criteria in acute and chronic liver disease. Hepatol 2009;50:538-45. http://dx.doi.org/10.1002/hep.23042.

32. Rubio-Tapia A, Hill ID, Kelly CP, Calderwood AH, Murray JA. American College Of Gastroenterology Clinical Guideline: Diagnosis and management of celiac disease. Am J Gastroenterol 2013;108:656-77. http://dx.doi.org/10.1038/ ajg.2013.79.

33. Tešija Kuna A. Serological markers of inflammatory bowel disease. Biochem Med (Zagreb) 2013;23:28-42. http:// dx.doi.org/10.11613/BM.2013.006.

34. Sciacovelli L, Secchiero S, Zardo L, Plebani M. The role of the external quality assessment. Biochem Med (Zagreb) 2010;20:160-4. http://dx.doi.org/10.11613/BM.2010.019.

35. Lippi G, Plebani M, Simundic AM. Quality in laboratory diagnostics: from theory to practice. Biochem Med (Zagreb) 2010;20:126-30. http://dx.doi.org/10.11613/BM.2010.014.

36. Bonaguri C, Melegari A, Ballabio A, Parmeggian $M, R u$ sso A, Battistelli $L$, et al. Italian multicentre study for application of a diagnostic algorithm in autoantibody testing for autoimmune rheumatic disease: Conclusive results. Autoimmun Rev 2011; 11:1-5. http://dx.doi.org/10.1016/j. autrev.2011.06.006. 